\title{
THE ROLE OF LOCAL COMMUNITIES IN SUSTAINABLE TOURISM DEVELOPMENT - NOTEĆ RIVER VALLEY CASE STUDY
}

\author{
HANNA MICHNIEWICZ-ANKIERSZTAJN, ${ }^{1}$ ALICJA GONIA, ${ }^{2}$ ANNA \\ DŁUŻEWSKA ${ }^{3}$
}

\author{
1 Kazimierz Wielki University in Bydgoszcz \\ Institute of Geography \\ e-mail: hanka@ukw.edu.pl \\ 2 Kazimierz Wielki University in Bydgoszcz \\ Institute of Geography \\ e-mail: alicja.gonia@ukw.edu.pl \\ 3 Marie Curie-Skłodowska University \\ Faculty of Earth Sciences and Spatial Management \\ e-mail: dluzewska.a@gmail.com
}

\section{JEL CODES}

KEYWORDS

ABSTRACT
Z130, Z320, Q560

ecotourism, local communities, protected areas, sustainable tourism, tourism product

This paper aims at illustrating the scope of involvement of local communities and local businesses in the development of cultural ecosystem services in rural areas, in particular with reference to sustainable tourism. The authors discuss if, how and why local communities develop ecotourism products and infrastructure in areas where natural and cultural resources are strictly controlled. This work is based on field surveys in the naturally valuable region of the Noteć River Valley, forming a part of International Waterway E70. Six focused interviews were carried out with employees of the indicated organisations and local residents who were involved in developing the offer of sustainable tourism and ecotourism. The results indicate that the local community more and more often realizes the existence of advantages related to operation in protected areas and utilizes local natural and cultural resources for the purposes of developing sustainable tourism, including ecotourism in their territory. It becomes an additional source of income, and for some people - the main one. At the same time, local cultural heritage, being a priority measure taken into account by the European Union, is protected. On a wider scale, such activities have a chance to develop in the Noteć River Valley if specialist and financial support is provided and if the residents' knowledge about ecotourism and their conscious involvement in the development of ecotourism increase. 


\section{Introduction and background}

Sustainable management of rural areas is a key normative concept used by politicians, experts and researchers when they relate the use of 'natural' landscapes to the concept of sustainability (Rist et al., 2007; Dłużewska, 2016). However, more and more frequently normalized rules of sustainable development of rural areas set out in the legislation of many countries encounter nonscientific knowledge of local communities (Rist et al., 2007; Saufi, O’Brien, Wilins, 2014). To some extent this necessitates a dialogue concerning sustainable development between local government authorities and local communities residing in the specific area. That way "this leads to understand sustainable rural development as the creation of 'social spaces' that enable the actors involved to shift from strategic to communicative action" (Rist et al., 2007, p. 36). In turn, this allows faster and better implementation of strategic assumptions concerning the specific area in practice.

Building a forum for dialogue is particularly important for rural areas and development of rural tourism (Fagioli, Diotallevi, Ciani, 2014). Their sustainable development requires an increasing involvement of social, economic and public actors in the socio-economic processes of change (Esparcia, 2014; Kuźniar, 2015; Marks-Krzyszkowska, Jeziorska-Biel, 2017). In addition, the necessity of creating local networks based on cooperation between local governments, associations and organizations as well as local businesses is emphasized (Wearing, McDonald, 2002; Beaumont, Dredge, 2010; Gascon 2013; Ruhanen, 2013). The latter group of stakeholders is expected to act according to the principles of sustainable business, taking into account, among other things: "ecological, social and economic value through offering products and services, sustainable supply chain management and distribute economic costs and benefits equitably among actors involved" (Schaltegger, Lüdeke-Freund, Hansen, 2016).

Authors of this article aimed at defining the role of involvement of local inhabitants and local business in cultural ecosystem services related to rural tourism, especially in relation to sustainability, delivery of products, and preparation of infrastructure for ecotourism in protected areas. The subject matter consists of depicting parties involved in the creation of products and tourism infrastructure.

The authors assumed that local communities should be involved in the development of tourism in protected areas since they have the best awareness of their existing natural and cultural potential. In addition, based on the experience of generations they can promote specific natural and cultural values for the needs of tourism, protecting them at the same time.

Various projects can be undertaken by local communities, authorities, companies, and also by NGOs, which can shape the tourism landscape according to the needs of sustainable tourism and of ecotourism (Balińska-Grzelak, 2012). For instance, these can be associations and local groups co-administrating the protected areas in various countries, e.g. in Japan (Hiwasaki, 2003), Australia (Ruhanen, 2013) or Romania (Buta, Holland, Kaplanidou, 2014). In the first case, associations operating in valuable natural areas such as Ogasawara Islands, Yakushima Island, and Shiretoko National Park, actively support the development of sustainable tourism, and at the same time carry out promotional, educational and training activities (stimulating economic activity) 
targeted at the residents. In Queensland area, described by Ruhanen, local government authorities and NGOs are to a large extent responsible for developing the tourist policy since no top-down initiatives exist in that respect. On the other hand, the example of residents making use of the Retezat National Park buffer zone in Romania leads to the conclusion that in case of strong positive ties to the place of residence and the encouragement from the authorities to manage the protected areas in a sustainable, environment-friendly manner, the residents are more willing to be involved in managing such areas. Puhakka (2008), describing the development of tourism in national parks in Finland, emphasizes that tourism activities developed by the residents and generating measurable socio-economic advantages for whole communities, is also an excellent argument in support of the idea of active protection of the natural and cultural heritage.

\section{Methodology}

The examples presented in the paper above include protected areas (in the frame of Nature 2000 programme) found around the Noteć River as those locations provide natural habitats for fauna and flora. The valley constitute an important ecological channel, in the same way it has a major potential in the development of sustainable tourism.

Firstly, the analysis of statistical data and secondary documents was applied in relation to the quality of environment and to socio-economic factors. In return, this method allowed for an objective evaluation of the applicability of the area under investigation to the analysis of the development of sustainable tourism. Secondly, authors studied a number of local planning documents and strategies. The readiness of local authorities to grant permissions for various activities related to tourism development was verified. Current projects with local communities involvement were investigated and described in detail. Here authors searched for cultural ecosystem services and their relation to sustainable tourism, ecotourism, and tourism products. Finally, a number of qualitative tests were applied. Structured interviews were conducted in November and December of 2015 among 6 individuals directly involved in tourism development at the investigated area. Local communities located in the valley of the Notec River were represented by the employees of: the Rural Advisory Centre in Minikowo responsible for the development of agritourism, organic farming, as well as the protection and promotion of local customs; the Ecomuseum which is the only one of its kind in the whole Kuyavian-Pomeranian region (NUTS 2); local authorities; and some delegates of local communities. All interviews were divided into two parts. The first part concentrated around the general involvement of local communities in the life of communes, and around the attitude of citizens to protected areas found in the vicinity of Noteć river. The second batch of questions focused on ecotourism, involvement of local communities in the development of tourism, and the evaluation of potentials for future development of tourism (tab. 1). 
Table 1. The structure of questions, pertaining to the role of local communities in the development of ecotourism in Noteć river valley in respect to research categories

\begin{tabular}{|c|c|}
\hline Category & Investigated issue \\
\hline \multirow{2}{*}{$\begin{array}{l}\text { General involvement of local communi- } \\
\text { ties in the life of the commune }\end{array}$} & Means of encompassing local communities in actions directed at local development \\
\hline & $\begin{array}{l}\text { Benefits of cooperation between communities, local authorities, NGOs, and entrepreneurs in } \\
\text { respect to local development }\end{array}$ \\
\hline \multirow[b]{2}{*}{ Attitude of citizens to protected areas } & Impact of protected areas on the life of communities \\
\hline & $\begin{array}{l}\text { Types and forms of tourism possible to develop in protected areas found in the vicinity of the } \\
\text { rivers }\end{array}$ \\
\hline \multirow{4}{*}{$\begin{array}{l}\text { Involvement of local communities in the } \\
\text { development of tourism }\end{array}$} & $\begin{array}{l}\text { Means of encompassing local communities in actions directed at the development of } \\
\text { sustainable tourism }\end{array}$ \\
\hline & Organising trainings, workshops, and consulting in relation to developing ecotourism offers \\
\hline & $\begin{array}{l}\text { Organising public consultations, discussions, and meetings in respect to the directions of } \\
\text { development of sustainable tourism }\end{array}$ \\
\hline & Sources of funds reserved for the development of sustainable tourism \\
\hline \multirow{6}{*}{$\begin{array}{l}\text { Evaluation of potentials for future devel- } \\
\text { opment of ecotourism }\end{array}$} & $\begin{array}{l}\text { Forms of sustainable tourism which can be develop in protected areas found in the vicinity } \\
\text { of the rivers }\end{array}$ \\
\hline & Initiators of activities related to ecotourism in protected areas found in the vicinity of the rivers \\
\hline & $\begin{array}{l}\text { Looking for connections between ecotourism and the tourism offer available in protected areas } \\
\text { found in the vicinity of the rivers }\end{array}$ \\
\hline & $\begin{array}{l}\text { Characteristics of tourism development - is it aligned with the protection of traditions and } \\
\text { identity, with respectful and responsible approach to current natural and cultural assets, } \\
\text { integration of local communities, and harmonious economic development of communes }\end{array}$ \\
\hline & $\begin{array}{l}\text { Evaluation of ecotourism as means of increasing numbers of tourists in protected areas found in } \\
\text { the vicinity of the rivers }\end{array}$ \\
\hline & $\begin{array}{l}\text { Obstacles in conducting activities by local communities directed at the development of ecotour- } \\
\text { ism offer }\end{array}$ \\
\hline
\end{tabular}

Source: authors' analysis.

This approach was verified by applying a few tools preferred by researches investigating sustainable tourism at local levels (Choi, Sirakaya, 2006; Gascon, 2013; Godfrey, 1998; Iorio, Corsale, 2014; Ruhanen, 2013).

\section{Results}

Bringing the sense of identity, belonging, and responsibility to local communities is one of major prerequisites for developing tourism in the investigated areas. This fact can be proven while investigating strategic planning in NUTS 2 Kuyavian-Pomeranian, especially with respect to communes located in the vicinity of the E70 waterway. These documents not only mention the approval, but also the necessity of including local communities in the life and development of communes. More often than not they require the mobilisation of local communities in the social and economic spheres of development. It is stated openly in strategic plans that local authorities encourage citizens to take active part in developing tourism. It is achieved through supporting local entrepreneurship, associations, local and groups of activists, through creating organisations and associations which are devoted to consulting in the sphere of tourism. Such goals are found, e.g., in the plans of Nakło nad Notecią (Nakło upon the Noteć River) commune. All of the investigated documents refer to the existing natural potential within the communes, making special note of protected areas, 
which can function as the basis for the development and promotion of tourism. Unfortunately, those positive factors - natural assets, promotion of organic farming, high quality of environment - do not translate into higher interests in pro-ecological tourism. Most communes are inclined to develop and promote rural tourism and agritourism, which naturally follow the characteristic features of those administrative units. In addition urban and urban-rural communes favour the development of culture tourism. Only two communes found in the Noteć Valley, namely Nakło and Sadki, list the possibility of developing eco-tourism in their strategic plans. This can result from the inclusion of those communes in Natura 2000 programme.

Stocktaking of current tourist offer confirms the goals and directions of tourism developing found in the strategic plans of investigated communes. The list encompasses tourism products based on natural potential; however, these are not directly linked to ecotourism. The offer is mostly prepared by citizens working in local organisations and associations in the valley the Noteć river. In the Noteć River valley these are the Partnership for Krajna and Patuki (Partnerstwo dla Krajny $i$ Patuk) and Three Valleys (Trzy Doliny) - a LAG that is also interested in the Brda and the Vistula rivers. On the one hand, they aim at integrating areas, and on the other they refer to the potential of each commune in its own right.

Having analysed development strategies of LAGs, the authors managed to find similarities in primary tasks defined by those groups. The analogies can be seen in: goals related to the sense of belonging to local areas, economic activisation of citizens, and finally actions aimed at rural and active eco-tourism. Only the Three Valleys and the Partnership for Krajna and Patuki are interested in organic farming, and only the latter differs from other LAGs by engaging in educational events and in developing eco-tourism.

All LAGs define their primary goal as tourism development which is achieved by the utilisation of ecosystem services (ES) and cultural ecosystem services (CES). The following specific objectives enumerated in their strategies are supposed to fulfil the tasks:

a) preservation and development of natural resources, of historical and cultural heritage, and of local identity - achieving this objective necessitates, besides renovating monuments, educating children, teenagers, and adults in relation to heritage found in their dwellings, upholding traditions and customs characteristic to the region, and supporting traditional crafts in order to prevent the disappearance of some professions;

b) promotion of assets, heritage, and local identity - this can be fulfilled by publishing texts, by organising events promoting local assets, and by developing and promoting local and traditional products;

c) improvement of tourism and recreation infrastructure and increase of the appeal of offered services - succeeding here depends on, e.g., providing a network of paths for biking, walking, horse riding, canoeing, as well as education tracks; in addition supporting infrastructure must be developed together with the number of sleeping and dining establishments;

d) creation of integrated tourism and culture offer in the areas covered by LAG activities.

The improvement of life quality is achieved by the development of: 
a) public spaces and infrastructure - cultural and sports centres in urban and rural areas, courts and pitches, which integrate local communities and increase their level of activities directed at local development; designing modern public buildings; developing services provided for communities;

b) entrepreneurship and new forms of non-agricultural activities;

c) social capital - this goal requires the creation of a substantial offer of courses, workshops, and trainings, which will allow to develop individual interests as well as to improve professional qualifications; in due course that should enhance the competitiveness at the job market; diversified offer of cultural, sport, recreation, and education events provided for children and teenagers, as this will warrant the development of their passions.

The authors noticed that tourist offer prepared by local communities revolves around recurring events, where primary importance is given to the presentation and promotion of local heritage, e.g., nature, dishes, culture. Quite often those products can be found in the List of Traditional Products managed by the Ministry of Agriculture and Rural Development. Various events mentioned before are organised by local authorities, tourism organisations, local associations, local action groups, and rural advisory centres. It is worth mentioning that programmes of those meetings often relate to ecological education, e.g., ecological education booths prepared by the Rural Advisory Centre in Minikowo. Among the most popular annual events one can list the following: Goose Festival in Przysiek and Minikowo, Carp Festival in Minikowo, and Summer in the countryside in Minikowo. This offer is garnished by selected restaurants which specialise in local dishes, and by local entrepreneurs and producers who deliver high quality organic food.

Despite the existing potential and declarations of local communities, who seemingly are interested in promoting local natural heritage, the number of eco-tourism products provided in the area is rather limited. The best offer characterises local communities spread in the lower section of the Noteć River. To exemplify one can refer to the Ecomuseum of the Noteć River Valley established by the local action group Partnership for the Development of Krajna and Pałuki (Partnerstwo na Rzecz Rozwoju Krajny i Pałuk). It gathers local entrepreneurs, restaurant owners, beekeepers, craftsmen, owners of agritourism farms who jointly present and promote natural heritage. In addition, the offer of the Noteć River Valley (Polish - Dolina Noteci) Nature Education Centre located in Minikowo increases the range of options. Most of the employees, who live in the valley of the Noteć River, hold ornithological camps, green schools, and cross country walks. After conducting the analysis of available examples, the authors concluded that in order to create a holistic and integrated ecotourism products, e.g., the Ecomuseum of the Noteć River Valley, numerous institutions, associations and representatives of local communities must work hand in hand. In addition, a wide information and promotional campaign should follow, as this will demonstrate the wealth of assets found in the vicinity of oblivious local communities. 


\section{Development of sustainable tourism and ecotourism in the opinion of reppesentatives of local communities}

The citizens dwelling in the Notec river valley are involved in the life of their communities, which must be perceived as a positive factor. Their actions are best visible in cooperating with local action groups, associations, and organisations. Communities also participate in various meetings and public consultations. All those can be seen as a result of perceiving potential benefits, e.g., availability of additional funds for investments and projects, or more efficient cooperation leading smoothly to desired objectives. To some extent, joint work is also understood as the factor integrating local communities, increasing safety, and mutual responsibility for the commune.

Local communities usually share a positive outlook on their existence in the valley of the Noteć river. Natural assets found near the rivers are perceived as an opportunity to develop local enterprises, to establish agritourism farms, to produce organic food, and finally to develop tourism based on the very natural assets. Local communities, taking into account the natural and cultural assets of the valleys, usually select the following forms of tourism as most appealing: active and educational tourism, event tourism, and also, though to a lesser extent, recreation and nature tourism. It may be symptomatic that local communities do not comprehend the extent of sustainable tourism, and as a result they do not perceive it as the major category to be developed in the region. Only on rare occasions are protected areas shunned as hindrance to the development of local entrepreneurship, as limitation to the scope of economic activity, or as the source of strict legalisations favouring the protection of environment.

Presently, local communities list agritourism and ornithological walks as the most popular. Secondly, outings, botanical workshops, trips devoted to finding and observing animals in their natural habitat, but also photographic and painting workshops are quite common. These are typically organised by local action groups, and less often by the administration of landscape parks or local authorities. Nevertheless, local communities find it problematic to identify the main initiator of ecotourism development, which may hint that the activities initiated by those groups are not as obviously noticeable, and hence, they are not understood as directed towards any specific objectives. It must be stated, though, that local action groups together with the Rural Advisory Centre in Minikowo are responsible for the preparation of numerous trainings, workshops, and public consultations relating to the development of sustainable tourism in the region. They also share their expertise in the creation of ecotourism offer. In the eyes of local communities, local authorities are much less productive in this sphere.

Local communities recognize benefits of developing ecotourism, especially in relation to natural assets of the river valleys praised in all questionnaires. Ecotourism is also perceived, more often than in the past, as an interesting alternative capable of increasing the number of tourists visiting the protected areas. Consequently, they pledge full and active support to the development. They justify their attitude by stating that ecotourism creates a niche, attracts tourists tired of urban clamour, enables supervision of natural and cultural assets, engages local communities, and finally 
distinguishes the region. It comes as no surprise that such an attitude is not only favourable but can become the source of ecotourism development and prosperity (fig. 1).

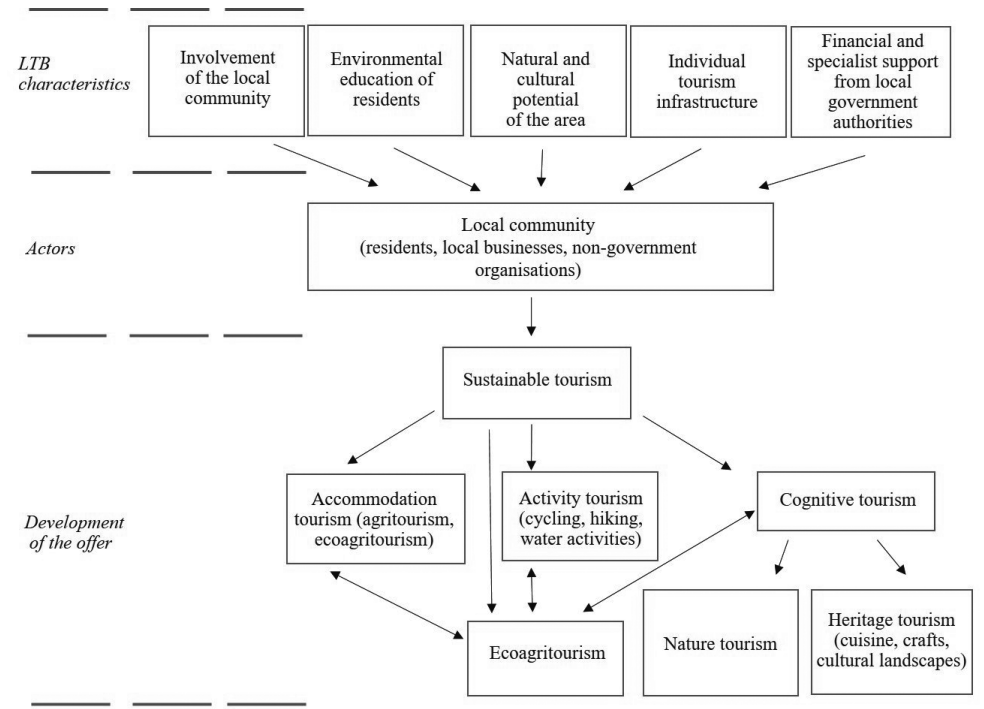

Figure 1. Involvement of the local communities in the development of sustainable tourism and ecotourism in the light of survey results

Source: own elaboration.

On the other hand, various opportunities to develop ecotourism are limited by factors indicated by local communities: ignorance of local communities in respect of the idea of ecotourism; lack of funding devoted to the development of ecotourism; mediocre support in terms of consultations and finances provided by local authorities; difficulties in obtaining requited certificates; and finally lack of prospects of substantial gains resulting from ecotourism enterprises. Majority of funds were obtained from the EU and Regional Marshal's Office. The length and complexity of the path to those funds is more than troublesome, or even impossible to traverse due to confusing red tape. In some cases prospective beneficiaries had no idea they could apply for such funds. As a result, a number of investments is balanced by the influx of private capital provided by local communities. The results of the survey indicate that respondents agree about the fact that managing the protected areas according to the principles of sustainable development can contribute to protection of such areas. At the same time, it offers an opportunity for social and economic development at the local level through bottom-up initiatives regarding the offer of sustainable tourism and ecotourism. Respondents indicate that a necessary condition for success in this respect is the cooperation between residents, local government authorities and Local Action Groups manifested in the transfer of knowledge (training, specialist project support), financial support and building of the feeling of local identity of the residents and their responsibility for the area they live in. 


\section{Discussion and conclusions}

The authors' research showed that the activity of the local community is an important element of sustainable management of natural heritage in the analyzed rural areas. With reference to utilization of this heritage for the purposes of tourism (and in particular its sustainable forms), both local government authorities and local associations, organizations, businesses are actively involved in the dialogue and cooperation. The attitude of the local communities presented in this paper complies with the results of studies by, among others, Hiwasaki (2003), Puhhaka (2008), Buta et al. (2014), Ruhanen (2013) and Gralak (2018). They list positive aspects of the activities undertaken by local communities for the development of sustainable tourism. At the same time, they point to cooperation between residents and the local government authorities and non-government organisations as a necessary condition for correct management of the protected areas.

With local government authorities the will to manage the natural heritage in a responsible manner is manifested in strategic documents which require residents to assume greater responsibility for developing the communes they live in. With extra-governmental organizations and associations, this responsibility is expressed in actual activity for the sake of environmental protection but also making the existing heritage available through creating sustainable tourism products.

In turn, comparing the activities of small businesses running tourist activities within the analyzed area to examples given in reference literature, it can be concluded that they have "a good grasp of sustainability concepts without knowing the theory" (Fassin, Van Rossem, Buelens, 2011). They still often undertake "sustainability actions without really disturbing the status quo of current practices" (Fassin et al., 2011). In connection with insufficient knowledge, a number of environmental and social measures it undertakes are more instinctive than well considered. Thus, continuing promotion and education of entrepreneurs on the principles of sustainable development and corporate social responsibility is very important, taking both economic as well as social, environmental and ethical goals into account.

\section{References}

Balińska-Grzelak, A. (2012). Rola partycypacji społecznej w stymulowaniu rozwoju turystyki. Ekonomiczne Problemy Turystyki, 20, 9-18.

Beaumont, N., Dredge, D. (2010). Local tourism governance: a comparison of three network approaches, Journal of Sustainable Tourism, 1 (18), 7-28.

Buta, N., Holland, S.M., Kaplanidou, K. (2014). Local communities and protected areas: The mediating role of place attachment for proenvironmental civic engagement. Journal of Outdoor Recreation and Tourism, 5-6, 1-10.

Choi, H., Sirakaya, E. (2006). Sustainability indicators for managing community tourism. Tourism Management, 27, 1274-1289.

Dłużewska, A. (2016). Cultural ecosystem services - framework, theories and practices. Problemy Ekorozwoju / Problems of Sustainable Development, 1 (12), 101-110.

Esparcia, J. (2014). Innovation and networks in rural areas. An analysis from European innovative Project. Journal of Rural Studies, 34, 1-14.

Fagioli, F.F., Diotallevi, F., Ciani, A. (2014). Strengthening the sustainability of rural areas: the role of rural tourism and agritourism. Rivista di Economia Agraria, 2-3, 155-169. 
Fassin, Y., Van Rossem, A., Buelens, M., (2011). Small-Business Owner-Managers' Perceptions of Business Ethics and CSR-Related Concepts. Journal of Business Ethic, 3 (98), 425-453.

Gascon, J. (2013). The limitations of community-based tourism as an instrument of development cooperation: the value of the Social Vocation of the territory concept. Journal of Sustainable Tourism, 5 (21), 716-731.

Godfrey, K.B. (1998). Attitudes towards 'sustainable tourism' in the UK: a view from local government. Tourism Management, 3 (19), 213-224.

Gralak, K. (2018). Partycypacja społeczna i jej znaczenie w rozwoju. Turystyka i rekreacja, 1 (21), $153-164$.

Hiwasaki, L. (2003). Tourism in Japan's Parks and Protected Areas: Challenges and Potential for Sustainable Development. International Review for Environmental Strategies, 1 (4), 107-126.

Iorio, M., Corsale, A. (2014). Community-based tourism and networking: Viscri, Romania. Journal of Sustainable Tourism, 2 (22), 234-255.

Kuźniar, W. (2015). Postawy lokalnej społeczności wobec rozwoju turystyki wiejskiej i ich konsekwencje dla obszaru recepcji. Nierówności Społeczne a Wzrost Gospodarczy, 2 (42), 296-305.

Lokalna Strategia Rozwoju LGD Gminy Powiatu Świeckiego Retrieved from: http://www.lgdswiecie.pl.

Lokalna Strategia Rozwoju LGD Partnerstwo dla Krajny i Pałuk. Retrieved from: http://www.fundacja-krajna-paluki.pl/.

Lokalna Strategia Rozwoju na lata 2008-2015 LGD Vistula - Terra Cumensis - Rozwój przez tradycję. Retrieved from: http://www.lgdvistula.org.

Lokalna Strategia Rozwoju na lata 2008-2015 LGD Zakole Dolnej Wisły. Retrieved from: http://www.zakolewisly.pl.

Lokalna Strategia Rozwoju Stowarzyszenia LGD Trzy Doliny na lata 2009-2015. Retrieved from: http://www.trzydoliny.eu.

Marks-Krzyszkowska, M., Jeziorska-Biel, P. (2017). Potencjał społeczności lokalnych w rozwoju turystyki Żuławek. Studia Obszarów Wiejskich, 46, 7-25.

Puhakka, R. (2008). Increasing role of tourism in Finnish National Parks. Fennia, 1 (186), 47-58.

Rist, S., Chidambaranathan, M., Escobar, C., Wiesmann, U., Zimmermann, A. (2007). Moving from sustainable management to sustainable governance of natural resources: The role of social learning processes in rural India, Bolivia and Mali. Journal of Rural Studies, 23, 23-37.

Ruhanen, L., 2013. Local government: facilitator or inhibitor of sustainable tourism development? Journal of Sustainable Tourism, 1 (21), 80-98.

Schaltegger, S., Lüdeke-Freund, F., Hansen, E.G. (2016). Business Models for Sustainability: A Co-Evolutionary A Local analysis of Sustainable Entrepreneurship, Innovation, and Transformation. Organization \& Environment, 3 (29), $1-26$.

Saufi, A., O’Brien, D., Wilins, H. (2014). Inhibitors to host community participation in sustainable tourism development in developing countries. Journal of Sustainable Tourism, 5 (22), 801-820.

Wearing, S., McDonald, M. (2002). The development of community based tourism: Re-thinking the Relationship Between Tour Operators and Development Agents as Intermediaries in Rural and Isolated Area Communities. Journal of Sustainable Tourism, 3 (10), 191-206. 


\section{ROLA SPOŁECZNOŚCI LOKALNYCH W ROZWOJU TURYSTYKI ZRÓWNOWAŻONEJ - PRZYKŁAD DOLINY NOTECI}

SŁOWA KLUCZOWE

STRESZCZENIE ekoturystyka, społeczności lokalne, obszary chronione, turystyka zrównoważona, produkt turystyczny

Poniższy artykuł ma na celu ukazanie zakresu zaangażowania społeczności lokalnych i lokalnych przedsiębiorstw w rozwój usług ekosystemu kulturowego na obszarach wiejskich, w szczególności w odniesieniu do zrównoważonej turystyki. Autorzy omawiają, czy, w jaki sposób i dlaczego, społeczności lokalne tworzą produkty i infrastrukturę ekoturystyczną na obszarach, na których zasoby przyrodnicze i kulturowe podlegają ścisłej kontroli. Niniejsza praca opiera się na badaniach terenowych prowadzonych w cennym przyrodniczo rejonie doliny Noteci, będącej częścią Międzynarodowej Drogi Wodnej E70. Przeprowadzono 6 ukierunkowanych wywiadów z pracownikami wskazanych organizacji oraz z mieszkańcami zaangażowanymi w tworzenie oferty turystyki zrównoważonej i ekoturystyki. Wyniki wskazują, że społeczność lokalna coraz częściej zdaje sobie sprawę z korzyści związanych z funkcjonowaniem na obszarach chronionych i wykorzystuje lokalne zasoby naturalne i kulturowe w celu rozwoju na swoim obszarze zrównoważonej turystyki, w tym ekoturystyki. Staje się to dodatkowym, a dla niektórych głównym źródłem dochodu. Jednocześnie chronione jest lokalne dziedzictwo kulturowe, będące priorytetowym miernikiem Unii Europejskiej. Na szerszą skalę takie działania mają szansę rozwinąc się w dolinie Noteci, przy specjalistycznym i finansowym wsparciu, a także, przy wzroście wiedzy mieszkańców na temat idei ekoturystyki oraz ich świadomym zaangażowaniu w działania na rzecz jej rozwoju. 